\section{Dead right}

M. B. Coleman et al. (J. biol. Chem. 266, 5798-5800; 1991) show how a misdiagnosis can be posthumously exposed: doctors, it seems, can no longer safely bury their mistakes. The Indianapolis variant of haemoglobin gives rise to a highly haemolytic $\beta$-thalassaemia. The mutation was reported as cys ${ }^{\beta 112} \rightarrow$ arg. But later this same substitution was found to attach to a milder condition, implying that the Indianapolis mutation had been incorrectly assigned. The two patients were by then dead, but a bone-marrow slide yielded DNA enough for detection of the mutation: leucine at $\beta 106$ had become arginine. Coleman and colleagues have renamed the (perhaps now extinct) variant haemoglobin Terre Haute.

\section{Size Is important}

MANY kinds of animals readily change sex, and according to one hypothesis it is likely to happen if fecundity increases with age or size in one sex more rapidly than in the other. Species of polychaete worm are good subjects for testing this idea (A. Berglund, Evolutionary Ecology 5, 128-135; 1991). Ophryotrocha puerilis males respond to the mid-life crisis by switching sex, but sex-change in the almost identical $O$. labronica is rare. Female choice may in fact be responsible: $O$. labronica females prefer large males, $O$. puerilis female small ones, presumably rejecting the larger males because they are in imminent danger of changing sex and competing with them - as females for mates. On reaching a certain size, then, males respond by making the ultimate sacrifice.

\section{Ring ratings}

THE buzz word associated with benzene is aromaticity - the ability to shuffle charge through its bonds for added stability. But what of its inorganic analogues?, ask W. H. Fink and J. C. Richards (J. Am. chem. Soc. 113 3393-3398; 1991). Borazine, a ring of alternating boron and nitrogen $\left(\mathrm{B}_{3} \mathrm{~N}_{3} \mathrm{H}_{6}\right)$, is well known, but is chemically very different from benzene, a difference that is put down to a lack of aromaticity. P. Power et al., colleagues of Fink and Richards, recently synthesized boronphosphorus analogues, but bulky substitutes for the hydrogen atoms confuse the picture of charge distribution around the ring. Fink and Richards resort to the computer and quantum calculations for a simpler answer, and suggest that boronnitrogen and boron-phosphorus analogues are half as aromatic as benzene, and that aluminium-nitrogen analogues hardly rate at all.

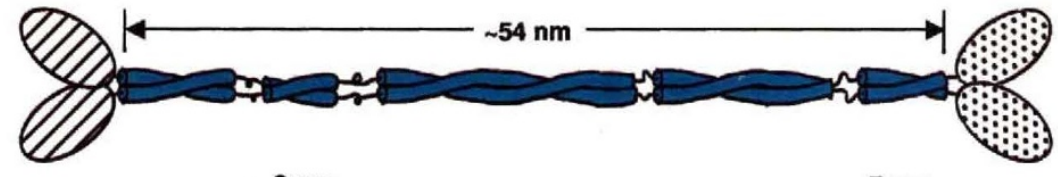

$6 \mathrm{~nm}$

$7 \mathrm{~nm}$

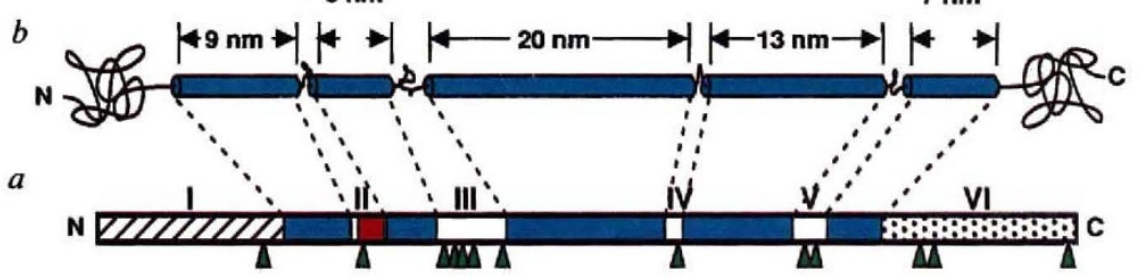

\section{Residue number}

FIG. 2 Rod-and-kink model of MCC structure. a, Location of sequence motifs in primary structure - blue, heptad repeator ('coiled coil'); red, sequence that is similar to that in the m 3 muscarinic acetylcholine receptor; green, prolines. $b$, Predicted domain structure of MCC monomer. $c$, Coiled coil structure of homodimer.

produce a 50 per cent decrease in MCC concentration and an intermediate functional deficit; strong dominant negative mutations could come close to abolishing MCC function altogether. This may explain how FAP causes colonic polyposis of different severities in different families, and in some families produces additional heritable defects, including abnormal development of teeth and bone and increased incidence of cancers in skin, brain and other organs, as well as cancer of the colon ${ }^{8}$.

Mild MCC alleles might also account for the increase in incidence of colonic polyps found in first-degree relatives of patients with 'sporadic' colon cancer, consistent with inheritance of a dominant mutation with variable penetrance ${ }^{9}$. Inheritance of such mild defects in one MCC gene might set the stage for tumour progression caused by subsequent deletion of the normal gene, a somatic mutation which would further diminish MCC function. Such a process could explain the substantial (20-30 per cent) incidence of $5 q 21$ deletions in apparently sporadic colon cancers. Similar reasoning could account for the detection ${ }^{10}$ of $5 q 21$ deletions in colonic cancers (but not adenomas) of FAP patients as well.

Man-made dominant negative mutations might help to identify what MCC does in normal cells. Expression of a dominantnegative $^{11}$ mutant MCC protein (for example one lacking either the $\mathrm{N}$ - or $\mathrm{C}$-terminal globular domains postulated in Fig. 2) would presumably impair MCC's spacing function. The resulting phenotype could reveal what that function is. Precedents include man-made mutations in nuclear lamins ${ }^{12}$, dominant paralysing mutations in a myosin heavy chain gene of Caenorhabditis elegans ${ }^{13}$, and myosin mutations associated with familial cardiomyopathy in humans ${ }^{14,15}$.

From the genetic point of view, $M C C$ in this model acts like another tumour suppressor gene, p53 (ref. 16). Mutations of $M C C$ in familial adenomatous polyposis, like $p 53$ mutations inherited in cancer-prone families with the Li-Fraumeni syndrome $^{17,18}$, induce tumours after a delay of several decades. Alternatively, somatic mutations in either the $M C C$ gene or the $p 53$ gene can contribute to tumour progression. As Vogelstein noted in his News and Views article ${ }^{16}$, "it is not the time of occurrence of mutations, but rather their accumulation, that is most important in tumour development".

Now is the time to lay your bets. Is MCC a G-protein inhibitor or a coiled coil? Weighing long stretches of heptad repeats against six identical amino acids, I am betting on the coiled coil. You may hedge your bets, of course, because the two hypotheses are not mutually exclusive. The MCC sequence that resembles the $\mathrm{m} 3$ muscarinic acetylcholine receptor is located in a kink between postulated rod-like regions (Fig. 2), where it could easily serve to attach $\mathrm{G}_{\mathrm{q}}$ to a macromolecular structure somewhere near the cytoplasmic face of the plasma membrane.

Henry R. Bourne is in the Departments of Pharmacology and Medicine and the Cardiovascular Research Institute, University of California, San Francisco, California 94143, USA.

1. Kinzler, K. W. et al. Science 251, 1366-1370 (1991).

2. Fearon, E. R. \& Vogelstein, B. Cell 61. 759-767 (1990).

3. Smrcka, A. V., Hepler, J. R., Brown, K. O. \& Sternweis, P. C. Science 251, 804-807 (1991).

4. Lechleiter, J. et al. EMBO J. 9, 4381-4388 (1990)

5. Neiman, A. M., Chang, F., Komachi, K. \& Herskowitz, I. Cell Reg. 1, 391-401 (1990).

6. McKeon, F. D., Kirschner, M. W. \& Caput, D. Nature 319 463-468 (1986).

7. Traub, P. Intermediate Filaments (Springer, Berlin, 1985).

8. Watne, A. L. \& Sohrabi, A. in Familial Adenomatous Poly posis (ed. Herrera, L.) 23-34 (Liss, New York, 1990).

9. Burt, R. W. in Familial Adenomatous Polyposis (ed. Herrera, L.) 17-22 (Liss, New York, 1990).

10. Sasaki, M. et al. Cancer Res. 49, 4402-4406 (1989).

11. Herskowitz, I. Nature 329, 219-222 (1987).

12. Heald, R. \& McKeon, F. Cell 61, 579-589 (1990)

13. Bejsovec, A. \& Anderson, P. Genes Dev. 2, 1307-1317 (1988).

14. Tanigawa, G. et al. Cell 62, 991-998 (1990)

15. Geisterfer, L. A. et al. Cell 62, 999-1006 (1990).

16. Vogelstein, B. Nature 348, 681-682 (1990)

17. Srivastava, S., Zou, Z., Pirollo, K., Blattner, W. \& Chang, E. H. Nature 348, 747-749 (1990)

18. Malkin, D. et al. Science 250, 1233-1238 (1990). 